\title{
Mitteilungen
}

\section{8th International Congress on the History of Science}

The First Circular for the XVIIIth International Congress on the History of Science, which will take place in Hamburg and Munich from 1 to 9 August, 1989, is now being distributed by the National Commissions and Societies for the History of Science and Technology. Please ask for your copy, if you have not yet received one, and return the reply card to Hamburg. The Second Circular will be mailed in the fall of 1988 directly to all colleagues who by returning the reply card have expressed interest in further information.

Prof. C. J.Scriba

Institut für Geschichte der Naturwissenschaften, Mathematik und Technik

Universität Hamburg

Bundesstraße 55

2000 Hamburg 13

F. R. of Germany

\section{Troisième Colloque international sur les Textes Médicaux Latins Antiques}

Le troisième Colloque international sur les Textes Médicaux Latins Antiques sera organisé par le Centre Jean Palerne (Université de Saint-Etienne et Centre National de la Recherche Scientifique. Il aura lieu les 11, 12 et 13 september 1989 à Saint-Etienne sur le thème Réalités et langage de la médecine dans le monde romain.

Pour tout renseignement complémentaire, s'adresser à

Professeur Guy SABBAH

Centre Jean-Palerne

Université de Saint-Etienne

2, rue Tréfilerie

F-42023 Saint-Etienne, Cedex 2 


\section{Call For Papers}

The seventh annual Conference of Cheiron-Europe (European Society for the History of the Behavioral and Social Sciences) will be held in Budapest, Hungary, 4-8 September 1988. The meeting will be organized by the Hungarian Psychological Association and the Institute of Psychology of the Hungarian Academy of Sciences.

Papers dealing with any aspect of the history of psychology and the related behavioral and social sciences and with philosophical and methodological problems in the historiography of these fields are invited.

Three symposia are planned at the conference:

- L.S. Vygotsky and his thought in the history of phsychology;

- Psychoanalysis in Central European context;

- Racism, eugenics and the social sciences.

Papers addressing themselves to the issues related to the above topics will be especially welcomed.

The deadline for submission of the papers is 1 April 1988. Papers should not exceed a maximum of 2000 words (approx. 7 pages, typed double-spaced). Papers may be submitted in either English, French, or German.-Papers should be sent to each member of the Programme Committee.

Programme Committee:

Ferene Erós (Inst. Psychology, Hungarian Academy of Sciences, Szondy u. 83-85,

H-1394 Budapest, Hungary);

Larry Ray (Departement of Sociology, University of Lancaster,

Lancaster LAl 4YG, United Kingdom);

Christfried Tögel (Bulgarian Academy of Sciences, Inst. Philosophy, Boul «Patr. Evtimii», 6 Sofia 1000, Bulgaria);

Fernando Vidal (14, chemin de la Caroline, 1213 Petit Lancy, Switzerland).

All enquiries and correspondence should be directed to Ferenc Erós

(adress above, phone (31-1) 382-344, extension 128). 


\section{PD Dr. phil. Heinz Balmer zum 60. Geburtstag}

Am 10.April 1988 begeht Herr PD Dr. phil. Heinz Balmer, ständiger wissenschaftlicher Mitarbeiter am Medizinhistorischen Institut der Universität Zürich, seinen 60. Geburtstag. H. Balmer wuchs im Seminar Hofwil, Münchenbuchsee, auf und erwarb am Städtischen Gymnasium in Bern die Matura. Nach anfänglichem Medizinstudium wechselte er zu den Fächern Geographie, Physik und Schweizergeschichte und promovierte 1953 mit der fast 900seitigen Arbeit «Beiträge zur Geschichte der Erkenntnis des Erdmagnetismus» zum Doktor der Naturwissenschaften. Nach einigen Jahren Unterrichtstätigkeit an der Sekundarschule Signau arbeitete er von 1964 bis 1969 als Assistent und Oberassistent am Geographischen Institut der Universität Bern. Seit 1969 widmet er sich vollamtlich der Geschichte der Naturwissenschaften und der Biologie, zuerst als wissenschaftlicher Mitarbeiter am Lehrstuhl für Geschichte der Naturwissenschaften und Technik der Universität Stuttgart (1969-1973), später am Medizinhistorischen Institut der Universität Bonn und seit 1974 am Medizinhistorischen Institut der Universität Zürich, wo er sich 1981 mit einer konzisen Darstellung von A.v. Hallers Leben und Werk für sein Fach habilitierte. H. Balmer gehörte von 1969 bis 1982 dem Vorstand der SGGMN an und war von 1976 bis 1980 bzw. 1982 Mit- bzw. Alleinredaktor des Gesnerus. Sprichwörtlich geworden ist H. Balmers Hilfsbereitschaft, die den zahlreichen Doktoranden und dem weiteren Benützerkreis des Zürcher Instituts zugute kommt.

Der Vorstand der SGGMN entbietet ihm seine besten Glückwünsche.

Redaktionsschlüsse für die nächsten Hefte des Gesnerus:

- 29. August 1988 für Heft 2/1988 (erscheint am 30. November 1988)

- 27. Februar 1989 für Heft $1 / 1989$ (erscheint am 31. Mai 1989)

- 29. August 1989 für Heft 2/1989 (erscheint am 30. November 1989) 